\title{
Sistem Informasi Pengkreditan Nasabah Pada Koperasi Simpan Pinjam Sejahtera Baru Kota Ternate Berbasis Web
}

\author{
Muhammad Samsudin ${ }^{1}$, Muhdar Abdurahman', Muksin Hi Abdullah ${ }^{3}$ \\ Program Studi Komputerisasi Akuntansi ${ }^{1}$, Politeknik Sains dan Teknologi Wiratama Maluku Utara \\ Program Studi Manajemen Informatika ${ }^{2}$, Program Studi Teknik Komputer ${ }^{3}$ \\ Akademi Ilmu Komputer Ternate \\ samsudin_12@yahoo.com
}

\begin{abstract}
Abstrak
Tujuan Penelitian ini untuk merancang sistem informasi pengajuan kredit berbasis Web pada Koperasi Simpan Pinjam Sejahtera Baru Kota Ternate. Penilitian dilakukan pada Koperasi Simpan Pinjam Sejahtera Baru Kota Ternate, Metode Pengumpulan Data yang digunakan adalah observasi dan wawancara dengan melakukan Analisa sistem dan merancang sistem dengan Model Berbasis Object, Sistem ini dibangun menggunakan Bahasa Pemrograman HTML, CSS, MySQL, dengan adanya sistem ini diharapkan memudahkan Pimpinan dalam pengambilan keputusan dengan proses monitoring hasil pengajuan kredit serta mempermudah nasabah dalam melakukan pengajuan kredit pada Koperasi Simpan Pinjam Sejahtera Baru Kota Ternate pada Website
\end{abstract}

\section{Kata kunci: Sistem Informasi, Kredit Nasabah, Website}

\begin{abstract}
The purpose of this research is to design information systems Web-based credit submission on Cooperative Loan Sejahtera Baru Ternate City, Doing research on Cooperative Loan Sejahtera Baru Ternate City, Data collection methods used are observation and interviews with system analysis and design of systems with Model-based Object, The system is built using programming languages HTML, CSS, MySQL. The existence of this system is expected to ease the leadership in the decision making process of monitoring results with the submission of a credit as well as simplify the customer in doing the filing of Credit Cooperative Loan Sejahtera Baru Ternate City on the Website
\end{abstract} Keywords: Information System, Customer Credit, Website

\section{PENDAHULUAN}

Untuk mencapai sasaran atau kegiatan maka penggunaan teknologi informasi yang handal menjadi kebutuhan untuk menghasilkan informasi yang cepat dan akurat. Pengguanaan komputer sebagai alat bantu untuk mengelola suatu pekerjaan menjadi kebutuhan yang sangat vital dimana informasi cepat dan akurat menjadi suatu hal yang sangat dibutuhkan pada saat ini.

Menurut Sudarwanto (2013) "Koperasi adalah badan usaha yang beranggotakan orang-orang atau badan hukum koperasi dengan melandaskan kegiatannya pada prinsip koperasi sekaligus sebagai gerakan ekonomi ranyat yang berdasarkan asas kekeluargaan.

Berpijak pada pokok pemikiran mengenai pengertian koperasi tersebut, maka pemahaman yang terkandung dalam pengertian koperasi tersebut adalah adalah Koperasi adalah suatu perkumpulan yang didirikan oleh orang-orang atau badan hukum koperasi yang memiliki keterbatasan kemampuan ekonomi, dengan 
tujuan untuk memperjuangkan peningkatan kesejahteraan anggotanya. Karena merupakan suatu perkumpulan, maka bentuk kerja sama yang dibangun koperasi bersifat sukarela, dan masingmasing anggota memiliki hak dan kewajiban yang sama. Mengingat tujuan koperasi untuk meningkatkan kesejahteraan anggota, maka masingmasing anggota berkewajiban dan memiliki tanggungjawab untuk mengembangkan serta mengawasi usaha koperasi. Untuk mewujudkan tujuan koperasi, maka dibenntuk badan usaha yang memiliki aktifitas usaha yang dikelola secara demokratis. Sebagai konsekuensi atas peran atau partisipasi anggota dalam mengembangkan usaha koperasi, maka resiko dan keuntungan usaha koperasi ditanggung bersama dan di bagi secara adil.

Koperasi simpan pinjam "Sejahtera Baru” merupakan suatu Badan usaha yang berada di kota Ternate yang bergerak pada Simpan Pinjam dalam kegiatan pelayanan koperasi. Banyak program pelayanan yang diberikan Koperasi Simpan Pinjam "Sejahtera Baru" kepada para nasabah, salah satunya adalah kegiatan pemberian kredit, dimana suatu program yang dikelola oleh Koperasi Simpan Pinjam "Sejahtera Baru" dalam pemberian bantuan kepada para nasabah dalam mengelola suatu usaha. Dalam pelayanan pengajuan kredit pada Koperasi Simpan Pinjam "Sejahtera Baru" masih menggunakan sistem manual sehingga sering terjadi kesalahan dalam pencatatan, pengelolaan data pengajuan kredit dan pelaporannya. Pengecekan data-data koperasi masih membutuhkan waktu lama karena harus mengantri dan memeriksa secara manual. Tingkat keamanan sistem penyimpanan data sangat rendah, karena buku dokumen menjadi arsip satu-satunya. sehingga pengelolaan data pengajuan kredit dan pelaporan menjadi kurang efektif dan akurat.

Berdasarkan uraian di atas, perlu adanya suatu sistem informasi yang dapat menyajikan informasi dengan mudah, cepat dan akurat dalam memberikan pelayanan yang memuaskan bagi nasabah. Proses pengolahan informasi dengan memanfaatkan teknologi Web menjadi media informasi yang efektif dan akurat

\section{Rumusan Masalah}

Bagaimana merancang Sistem Informasi Pengajuan Kredit berbasis Web pada Koperasi Simpan Pinjam " Sejahtera Baru" Kota Ternate

\section{Tujuan Penelitian}

1. Untuk merancang sistem informasi pengajuan kredit berbasis Web pada Koperasi Simpan Pinjam "Sejahtera Baru" Kota Ternate.

2. Untuk mempermudah nasabah dalam pengajuan kredit pada Koperasi Simpan Pinjam "Sejahtera Baru" Kota Ternate.

\section{Manfaat Penelitian}

1. Demi meningkatkan kinerja dan pelayanan pada Koperasi Simpan Sejahtera Baru yang efektif dan efisiensi pengelola data-data transaksional.

2. Memudahkan Pimpinan dalam pengambilan keputusan dengan proses monitoring hasil pengajuan kredit Berbasis Web.

\section{Tinjauan Pustaka}

Duwi Cahya Putri Buani dalam judul Perancangan Sistem Informasi Koperasi Simpan Pinjam Studi Kasus: Koperasi 
SMK 18 LPPM RI Sidareja Cilacap mengatakan bahwa Koperasi Simpan Pinjam SMK 18 LPPM RI Sidareja merupakan koperasi yang memfasilitasi staf dan guru SMK 18 LPPM RI Sidareja untuk melakukan pinjaman, dan simpanan. Kepala Perpustakaan sering kesulitan dalam menentukan anggota Koperasi yang memiliki spesifikasi berhak mendapatkan pinjaman, sering terjadi kesalahan pencatatan data, sering terjadi kehilangan data dan kurang efektif dan efisien dalam melakukan pelayanan. Dengan Sistem Informasi Koperasi Simpan Pinjam ini diharapka semua permasalahan tersebut terpecahkan. Metode Waterfall merupakan metode yang sangat mudah diikuti dari Setiap tahapannya, dengan tahapantahapan yang ada dimetode waterfall maka sistem terdokumentasi dengan baik. Setiap tahapan tidak dapat dilewati sehingga peneliti atau perancang sistem dapat lebih fokus pada setiap tahapannya.

Dian Gigih Indrawati pada Naskah Publikasi Skripsi yang berjudul Sistem Informasi Simpan Pinjam Pada Koperasi Sedai Kec. Tangen menggunakan PHP MySQL dan SMS Gateway mengatakan bahwa Di koperasi "Sedia" Kec.Tangen pengelolaan transaksi simpanan, pinjaman maupun angsuran masih secara manual atau pembukuan dan tidak tertata rapi. Tidak dapat dihindari pencatatan secara manual rentan akan kesalahan, maka Koperasi "Sedia" Kec.Tangen ini membutuh suatu sistem informasi perangkat lunak yang menggantikan pekerjaan yang awalnya masih secara manual menjadi berbasis komputer yang di lengkapi fitur SMS Gateway yang akan memberikan informasi tentang jumlah simpanan, jumlah pinjaman dan angsuran tiap bulannya. Berdasarkan hasil kuisioner menunjukka bahwa $84 \%$ dari 20 responden menunjukkan bahwa sistem yang dibuat sangat membantu dalam penyimpanan data secara komputerisasi

\section{LANDASAN TEORI \\ Karakteristik Sistem}

Karakteristik Sistem menurut Sutanto (2004), adalah adanya tujuan tujuan sistem; batas sistem; subsistem; Hubungan sistem; lingkungan sistem; dan input, proses dan output, untuk lebih jelasnya karakteristik sistem akan di uraikan sebagai berikut:

\section{a. Komponen Sistem (Componen)}

Suatu sistem terdiri dari sejumlah komponen yang saling berinteraksi, artinya saling bekerja membentuk satu kesatuan. Komponen-komponen sistem tersebut dapat berupa suatu bentuk subsistem. Setiap subsistem memiliki sifat dari sistem yang menjalankan suatu fungsi tertentu dan mempengaruhi proses sistem secara keseluruhan. Suatu sistem dapat menpunyai sistem yang lebih besar atau sering disebut "supra sistem".

b. Batas Sistem (Boundary)

Batas sistem merupakan garis abstraksi yang memisahkan antara sistem dan lingkungannya. Batas sistem ini bagi umat manusia sangat relatif dan tergantung kepada tingkat pengetahuan dan situasi kondisi yang dirasakan oleh orang yang melihat sistem tersebut.

\section{c. Lingkungan Luar Sistem (Environment)}

Bentuk apapun yang ada diluar rung lingkup atau batasan sistem yang mempengaruhi operasi sistem tersebut disebut luar sistem. Lingkungan luar sistem ini dapat bersifat menguntungkan dan dapat juga bersifat merugikan sistem tersebut. Dengan demikian, lingkungan luar tersebut 
harus tetap dijaga dan dipelihara. Lingkungan luar yang merugikan harus dikendalikan. Kalau tidak maka akan menggangu kelangsungan hidup sistem tersebut.

\section{d. Penghubung sistem (Interface)}

Media yang menghubungkan sistem dengan subsistem lain disebut penghubung sistem atau interface. Penghubung ini memungkinkan sumber-sumber daya yang mengalir dari satu subsistem ke subsistem yang lain. Bentuk keluaran dari suatu subsistem akan menjadi masukan untuk subsistem lain melalui penghubung tersebut. Dengan demikian, dapat terjadi suatu integrasi sistem yang membetuk satu kesatuan.

e. Masukan Sistem (Input)

Energi yang dimasukkan ke dalam sistem disebut masukan sistem, yang dapat berupa pemeliharaan dan sinyal. Contoh, di dalam suatu unit sisten komputer, "program" adalah maintenance input yang digunakan untuk mengoperasikan komputernya dan "data" adalah signal input untuk diolah menjadi informasi.

\section{f. Keluaran Sistem}

Hasil energi yang diolah dan diklasifikasikan menjadi keluaran yang berguna keluaran ini merupakan masukan bagi susbsistem yang lain seperti sistem informasi. Keluaran yang dihasilkan adalah informasi. Informasi ini dapat digunakan sebagai masukkan untuk pengambilan keputusan utau hal-hal yang lain yang menjadi input bagi subsistem lain.

\section{g. Pengelohan sistem (Proseccing)}

Suatu sistem dapat mempuyai suatu proses yang akan mengubah masukan menjadi keluaran, contohnya adalah sistem akuntansi. Sistem ini akan mengelola data transaksi menjadi laporan-laporan yang dibutuhkan oleh pihak manajemen.

h. Sasaran sistem (objektive) atau tujuan (goal)

Suatu sistem yang harus memiliki sasaran (objective) dan tujuan (goal) yang pasti dan bersifat deterministic. Kalau suatu sistem tidak memiliki sasaran maka operasi sistem tidak ada gunanya. Suatu sistem dikatakan berhasil jika mengenai sasaran atau tujuan yang telah direncanakan.

\section{Tujuan Sistem}

Menurut Taufiq (2013), tujuan sistem merupakan sasaran atau hasil yang diingikan Manusia, tumbuhan, hewan organisasi, lembaga dan lain sebagainya pasti memiliki tujuan yang bermanfaat minimal bagi dia sendiri atau bagi lungkungannya

\section{Sistem Informasi}

Menurut Sutabri (2012), "Sistem Informasi adalah suatu sistem di dalam suatu organisasi yang mempertemukan kebutuhan pengolahan transaksi harian yang mengdukung fungsi operasi organisasi yang bersifat menejerial dengan kegiatan strategi dari suatu organisasi untuk dapat menyediakan laporan-laporan oleh pihak luar terntentu".

\section{Tujuan Sistem Informasi}

Menurut Sri Dewi Anggadini (2014), "tujuan sistem informasi yaitu untuk menghasilkan produk informasi yang tepat bagi para pemakai akhir. Produk informasi meliputi pesan, laporan formulir dan gambar grafik, yang dapat disediakan melalui tampilan video, respons audio, produk kertas, dan multimedia 


\section{Analisa Sistem}

Menurut Yakub (2012) "Analisa sistem dapat diartikan sebagai suatu proses untuk memahami sistem yang ada, dengan menganalisa jabatan dan uraian tugas, Proses bisnis, ketentuan atau aturan, masalah dan mencari solusinya, dan rencana-rencana perusahaan

\section{Definisi dan Tujuan Kredit}

Menurut Kasmir (2012), mengatakan bahwa: " Dalam bahasa latin kredit disebut credere yang artinya percaya. Maksudnya si pemberi kredit percaya kepada si penerima kredit yang disalurkan pasti akan dikembalikan sesuai dengan perjanjian. Sedangkan bagi si penerima kredit berarti menerima kepercayaan, sehingga mempunyai kewajiban untuk membayar kembali pinjaman tersebut sesuai dengan jangka waktunya.

Adapun tujun utama pemberian suatu kredit adalah sebagai berikut

\section{a. Mencari keuntungan}

Yaitu bertujuan untuk memperoleh hasil dari pemberian kredit tersebut. Hasil tersebut terutama dalam bentuk bunga yang diterima oleh koperasi sebagai balas jasa dan biaya administrasi kredit yang dibebankan kepada nasabah, keutungan ini penting untuk kelangsungan hidup koperasi. Jika koperasi terus-menerus menderita kerugian, maka besar kemungkinan koperasi tersebut akan dilikuidasi (dibubarkan).

b. Membantu Usaha Nasabah

Disamping unsur percaya didalam kredit juga mengandung unsur kesepakatan antara si pemberi kredit dengan si penerima kredit. Kesepakatan ini dituangkan dalam suatu perjanjian di mana masing- masing pihak mendatangani hak dan kewajibannya masing-masing.

\section{c. Membantu Pemerintah}

Bagi pemerintah semakin banyak kredit yang disalurkan oleh pihak koperasi, maka semakin baik, mengingat semakin banyak kredit berarti adanya peningkatan pembangunan di berbagai sektor.

\section{Pinjaman}

Pengertian Pinjaman menurut Peraturan Pemerintah Republik Indonesia Nomor 9 Tahun 1995 tentang kegiatan usaha Simpan Pinjam, yaitu sebagai berikut: "Pinjaman uang atau tagihan yang dapat dipersamakan dengan itu, berdasarkan persetujuan atau kesepakatan pinjam-meminjam antara koperasi dengan pihak lain yang mewajibkan pihak peminjam untuk melunasi hutangnya setelah jangka waktu tertentu dan disertai dengan pembayaran sejumlah imbalan

\section{Nasabah}

Menurut (Sunarno) nasabah adalah suatu badan perorangan yang melakukan kredit/pinjaman dengan pihak lain, dalam hal ini dengan Koperasi yang telah disepakati antara kedua belah pihak dengan peraturan-peraturan yang telah ditetapkan berdasarkan hukum yang berlaku.

\section{PHP}

Supono dan Putratama (2016:3) mengemukakan bahwa "PHP (PHP: Hypertext Preprocessor) adalah suatu bahasa pemrograman yang digunakan untuk menerjemahkan baris kode program menjadi kode mesin yang dapat dimengerti oleh komputer yang berbasis server-side yang dapat ditambahkan ke dalam HTML". Sedangkan, menurut Solichin 
(2016:11) mengemukakan bahwa "PHP merupakan salah satu bahasa pemrograman berbasis web yang ditulis oleh dan untuk pengembang web".

\section{HTML}

Menurut Solichin (2016:10) mengemukakan bahwa "HTML merupakan bahasa pemrograman web yang memberitahukan peramban web (web browser) bagaimana menyusun dan menyajikan konten di halaman web".

\section{MySQL}

Menurut Grolt dalam Fauzi dan Amin (2012:37) mengemukakan bahwa "SQL merupakan sebuah alat untuk melakukan proses organisasi, manajemen, dan pengambilan data yang tersimpan dalam sebuah database".

\section{XAMPP}

Menurut Betha Sidik XAMPP ( $\mathrm{X}$ (windows/ Linux) Apache MySQL PHP dan Perl) merupakan paket server web PHP dan database MySQL yang paling popuper dikalangan pengembangan web dengan menggunakan PHP dan PySQL sebagai databasenya

\section{Flowchart}

Flowchart atau bagan alir adalah bagan (chart) yang menunjukkan alir (flow) di dalam program atau prosedur sistem secara logika. Bagan alir (flowchart) digunakan terutama untuk alat bantu komunikasi dan untuk dokumentasi.

\section{UML (Unifield Modelling Languange)}

Unified Modeling Language (UML) adalah salah satu standar bahasa yang banyak digunakan di dunia industri untuk mendefinisikan requirement, membuat analisis dan desain, serta menggambarkan arsitektur dalam pemrograman berorientasi objek. UML merupakan bahasa visual untuk pemodelan dan komunikasi mengenai sebuah sistem dengan menggunakan diagram dan teks-teks pendukung. UML hanya berfungsi untuk melakukan pemodelan. Jadi penggunaan UML tidak terbatas pada metodologi tertentu, meskipun pada kenyataannya UML paling banyak digunakan pada metodologi berorientasi objek (Rosa A.S dan M. Shalahudin, 2014:133).

\section{METODE PENELITIAN}

\section{Jenis dan Sumber Data}

a. Data Primer, yaitu jenis data yang diperoleh langsung pada objek penelitian melalui wawancara langsung dengan Pimpinan Kopersi Simpan Pinjam Sejahtera Baru Kota Ternate.

b. Data Sekunder yaitu data yang berupa dokumen-dokumen atau laporanlaporan lainnya yang relefan dengan penelitian ini.

\section{Metode Pengumpulan Data}

Adapun metode yang digunakan dalam penelitian ini yaitu dengan mengirimkan surat permohonan penelitian pada instansi (Koperasi Simpan Pinjam Sejahtera Baru Kota Ternate), dan setelah surat balasan diterima untuk melakukan penelitian dan pengambilan data di Koperasi maka mulai melakukan observasi dan wawancara dengan anggota Koperasi yang menangani urusan pinjaman kredit anggota

\section{Alur Penilitian}




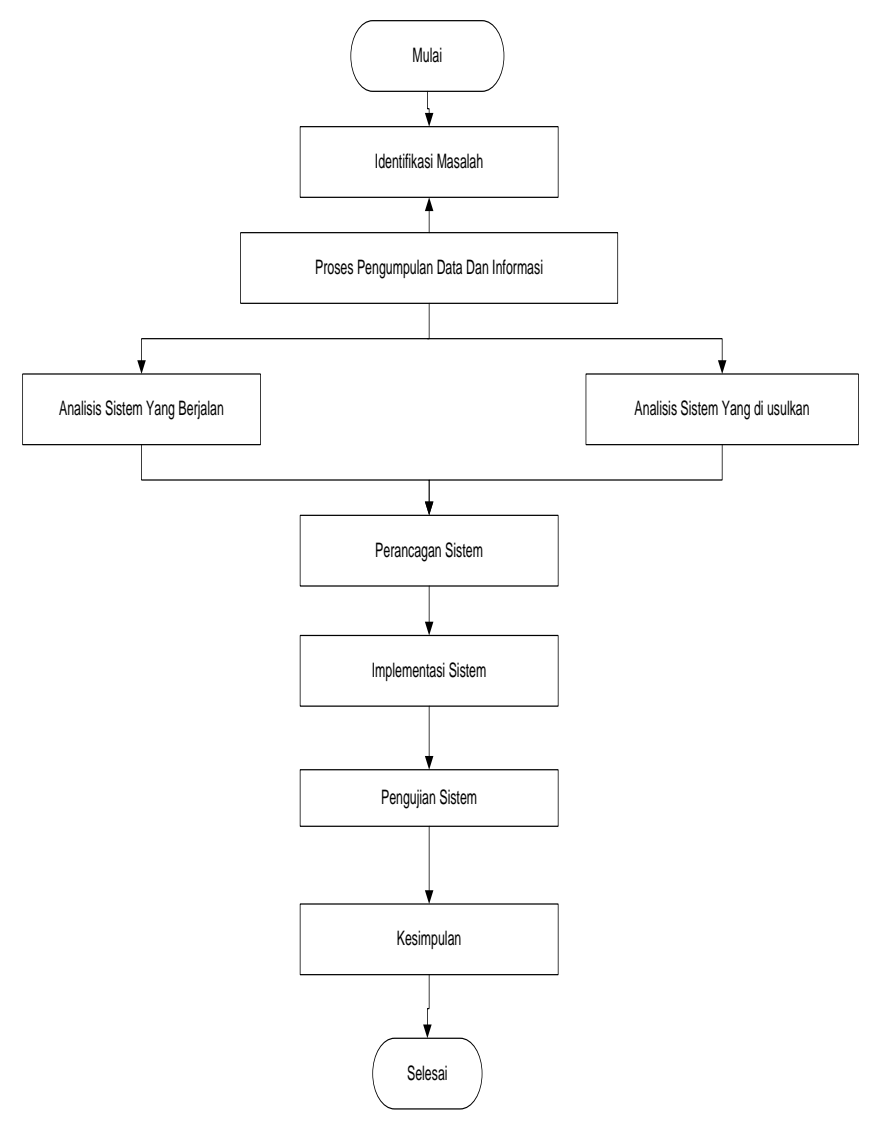

Gambar 1. Kerangka Berpikir

\section{ANALISIS DAN PERANCANGAN Spesifikasi Perangkat Keras}

Tabel 1. Spesifikasi Perangkat Keras

\begin{tabular}{|c|c|c|c|}
\hline No & $\begin{array}{l}\text { Perangkat } \\
\text { Keras }\end{array}$ & Jumlah & Keterangan \\
\hline 1. & $\begin{array}{l}\text { NoteBook } \\
\text { (Laptop0 }\end{array}$ & 1 Unit & $\begin{array}{l}\text { a. Processor intel } \\
\text { Atom. } \\
\text { b. Mainbord intel } \\
\text { Atom. } \\
\text { c. RAM } 2 \text { GB. } \\
\text { d. Hardisk } 500 \\
\text { GB } \\
\text { e. LCD Tosiba } 32 \\
\text { bit } \\
\text { f. Printer Canon } \\
258 \mathrm{Mp}\end{array}$ \\
\hline 2 & Catu daya & 1 Unit & Charger 20 Volt \\
\hline
\end{tabular}

\section{Spesifikasi Perangkat Lunak}

Tabel 2. Spesifikasi Perangkat Lunak

\begin{tabular}{|l|l|l|}
\hline No & Perangkat Lunak & Keterangan \\
\hline 1 & $\begin{array}{l}\text { Sistem Operasi } \\
\text { winduws 7 ultimate }\end{array}$ & Sistem Operasi \\
\hline
\end{tabular}

\begin{tabular}{|l|l|l|}
\hline 2 & Microsoft Office & Tools Pengetikan \\
\hline 3 & Microsoft Visio & $\begin{array}{l}\text { Desain } \\
\text { Perancangan } \\
\text { Sistem }\end{array}$ \\
\hline 4 & $\begin{array}{l}\text { Enterprise } \\
\text { Architecture (EA) }\end{array}$ & $\begin{array}{l}\text { Desain } \\
\text { Perancangan } \\
\text { Sistem }\end{array}$ \\
\hline 5 & $\begin{array}{l}\text { Macromedia } \\
\text { Desain Tampilan } \\
\text { Sistem }\end{array}$ \\
\hline 6 & Xampp & Web server \\
\hline 7 & MySQL & Database \\
\hline 8 & Mozilla Firefox & Web Browser \\
\hline
\end{tabular}

\section{Analisa Sistem}

Ada beberapa prosedur yang harus dilakukan dalam melakukan kegiatan pengajuan kredit yang sedang berjalan pada saat ini KSP Sejahtera Baru Kota Ternate sebagai berikut

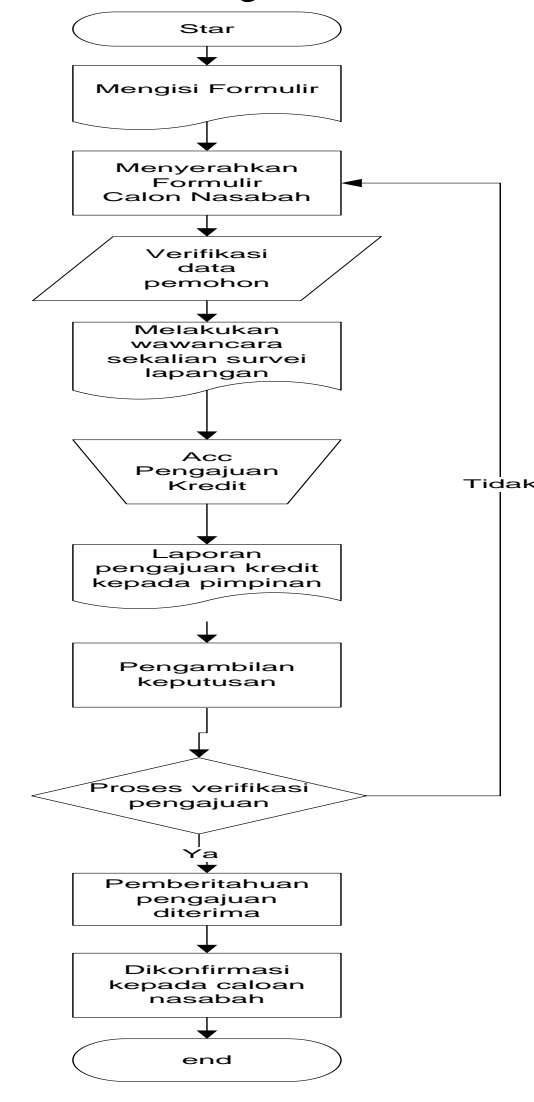

Gambar 2. Analisis Sistem berjalan

Kelemahan-kelemahan yang terdapat dalam sistem yang sedang berjalan antara lain: 
1. Para Anggota yang hanya mau mengetahui informasi sisa angsuran dengan cara berkunjung ke kantor tersebut

2. Pengecekan data-data Koperasi masih membutuhkan waktu lama karena harus mengantri dan memeriksa secara manual

3. Tingkat keamanan sistem penyimpanan data sangat rendah, karena buku dokumen menjadi arsip satu-satunya.

Untuk mengatasi berbagai permasalahan yang terdapat pada sistem yang sedang berjalan, maka pada bagian ini dikembangkan sistem berbasi Web Web. Adapun sistem yang diusulkan dapat dilihat pada gambar berikut

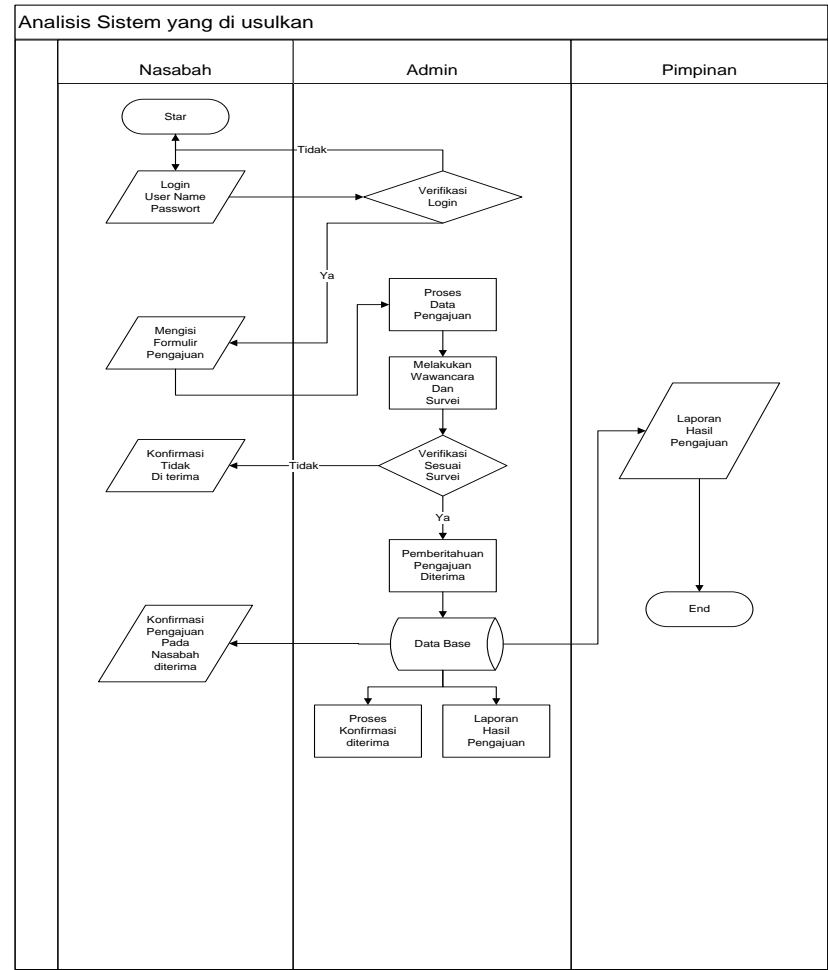

Gambar 3. Analisis Sistem yang diusulkan

\section{Rancangan Sistem}

Tabel 3. Tabel Admin

\begin{tabular}{|l|l|l|l|l|}
\hline Nomor & Nama & Type & Nilai & \multicolumn{1}{|c|}{ Ket } \\
\hline 1 & Id & Int & 2 & $\begin{array}{l}\text { Primary } \\
\text { Key }\end{array}$ \\
\hline
\end{tabular}

\begin{tabular}{|l|l|l|l|l|}
\hline 2 & Username & Varchar & 30 & \\
\hline 3 & Password & Varchar & 200 & \\
\hline
\end{tabular}

Tabel 4. Data Nasabah

\begin{tabular}{|l|l|l|l|l|}
\hline $\begin{array}{c}\text { No } \\
\text { mor }\end{array}$ & \multicolumn{1}{|c|}{ Nama } & \multicolumn{1}{|c|}{ Type } & Nilai & Ket \\
\hline 1 & Kd_nasabah & Char & 6 & $\begin{array}{l}\text { Primary } \\
\text { Key }\end{array}$ \\
\hline 2 & $\begin{array}{l}\text { Nama_nasab } \\
\text { ah }\end{array}$ & Varchar & 100 & \\
\hline 3 & Kelamin & Enum & - & \\
\hline 4 & Pekerjaan & Varchar & 30 & \\
\hline 5 & Penghasilan & Varchar & 20 & \\
\hline 6 & Email & Varchar & 100 & \\
\hline 7 & Alamat & Varchar & 40 & \\
\hline 8 & No_telepon & Varchar & 20 & \\
\hline 9 & Username & Varchar & 20 & \\
\hline 10 & Password & Varchar & 100 & \\
\hline 11 & Tanggal & Date & - & \\
\hline
\end{tabular}

Tabel 5. Data Konfirmasi

\begin{tabular}{|l|l|l|l|l|}
\hline $\begin{array}{c}\text { No } \\
\text { mor }\end{array}$ & \multicolumn{1}{|c|}{ Nama } & \multicolumn{1}{|c|}{ Type } & $\begin{array}{c}\text { Nila } \\
\text { i }\end{array}$ & \multicolumn{1}{|c|}{ Ket } \\
\hline 1 & Id & Int & 4 & $\begin{array}{l}\text { Primary } \\
\text { Key }\end{array}$ \\
\hline 2 & No_pinjaman & Varchar & 8 & \\
\hline 3 & Nama_nasabah & Varchar & 100 & \\
\hline 4 & Jumlah_pinjaman & Int & 12 & \\
\hline 5 & Keterangan & Text & - & \\
\hline 6 & Tanggal & Date & - & \\
\hline
\end{tabular}

\section{Use Case Diagram Sistem}

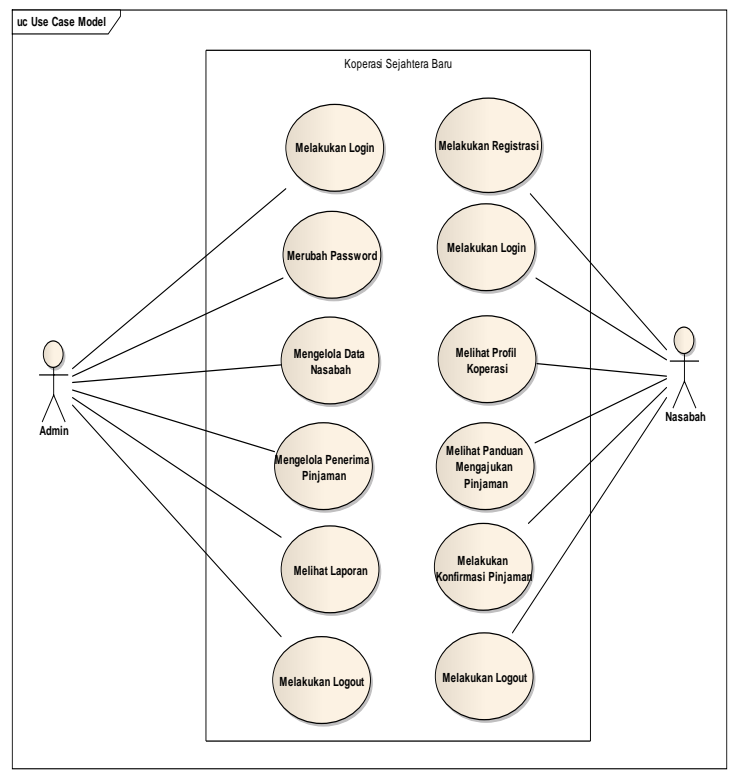

Gambar 4. Use Case Sistem Pengkreditan

Diagram Activity Login Admin 


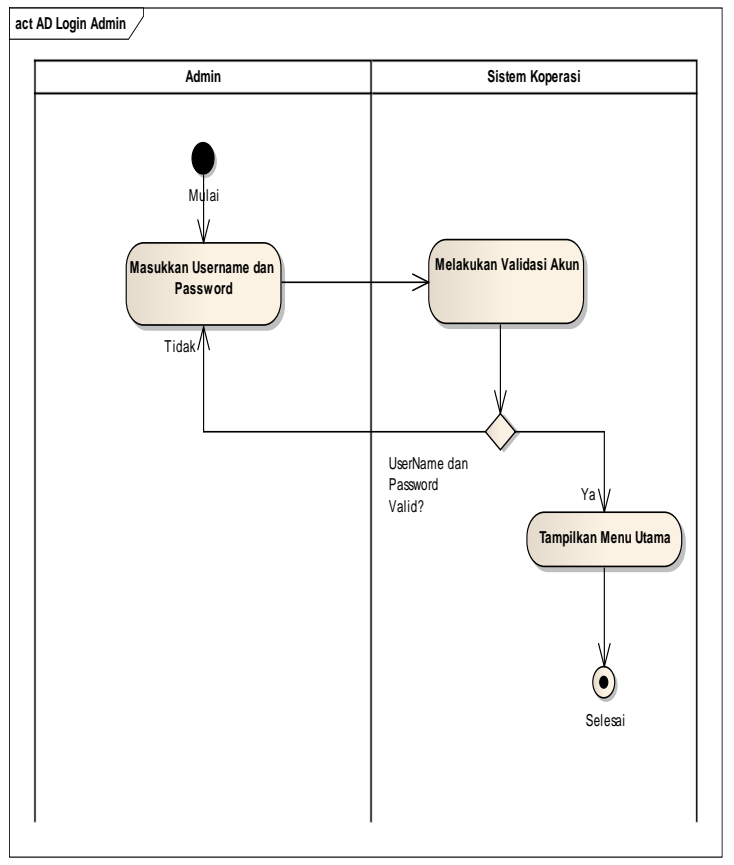

Gambar 5. Diagram Activity Login Admin

\section{Diagram Activity Mengelola Data Nasabah}

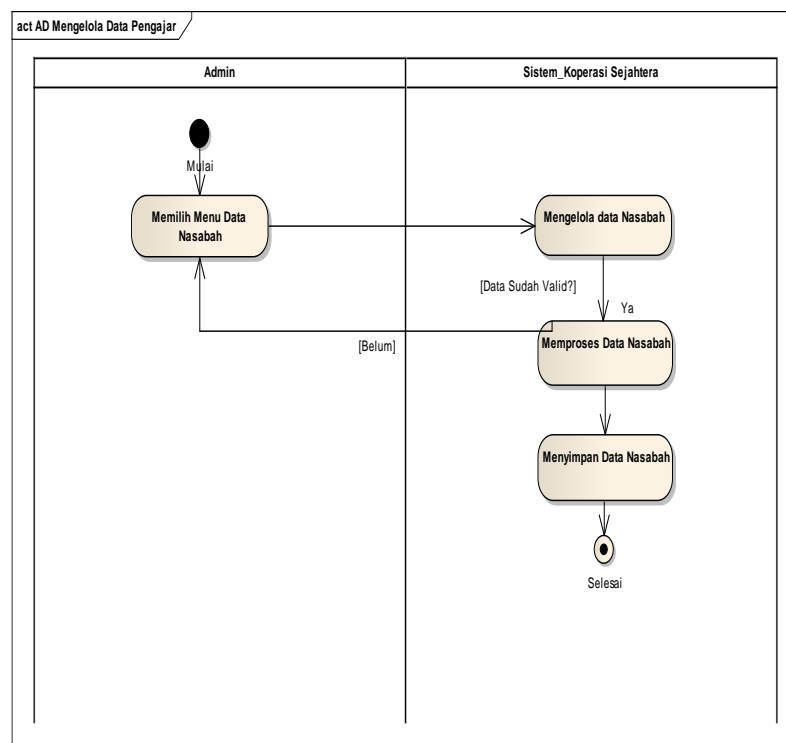

Gambar 6. Activity Data Nasabah

Diagram Activity Mengelola Data Pinjaman

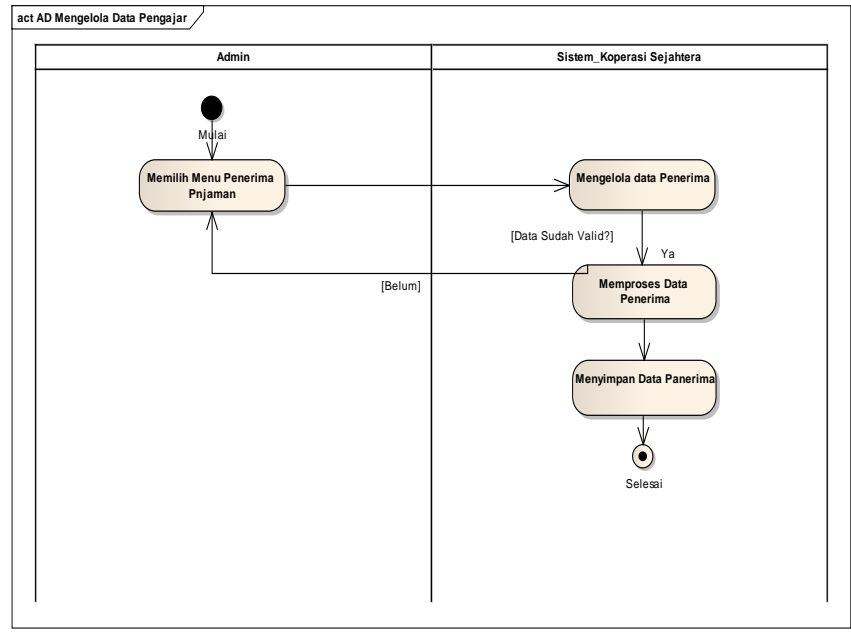

Gambar 7. Diagram Activity Data Pinjaman

\section{Diagram Activity Laporan}

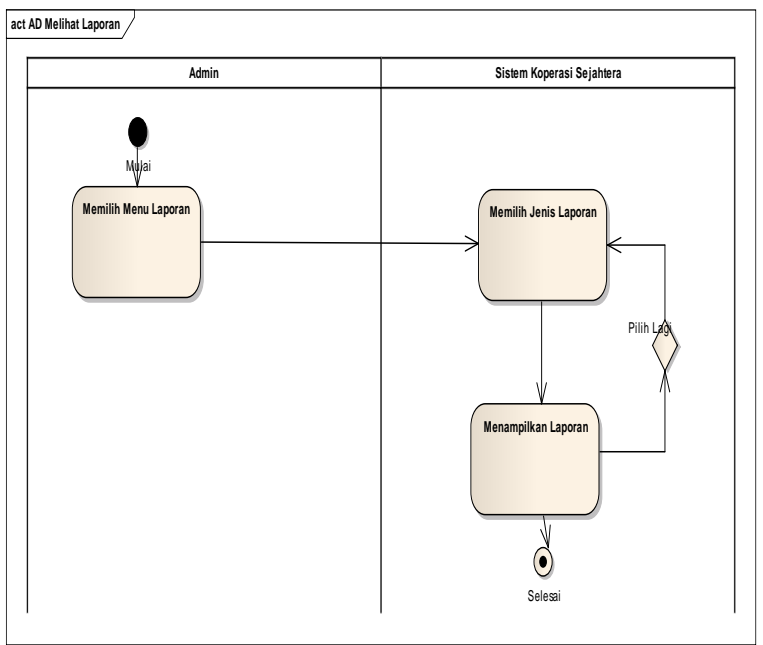

Gambar 8. Diagram Activity Laporan

\section{Diagram activity Nasabah registrasi}

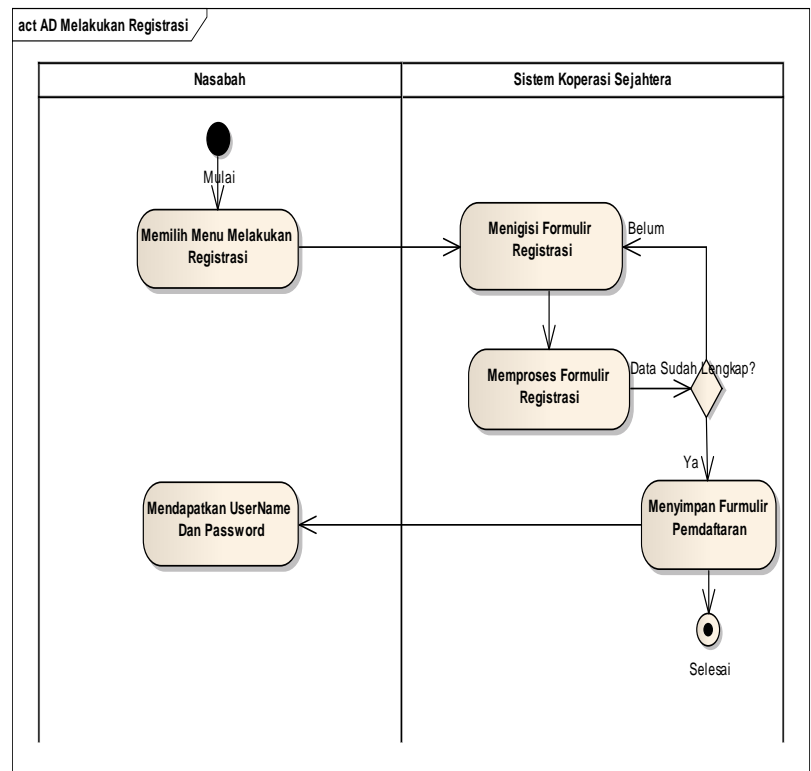


Gambar 9. Diagram Activity Nasabah Regitrasi

Diagram Sequence Melakukan Login Admin

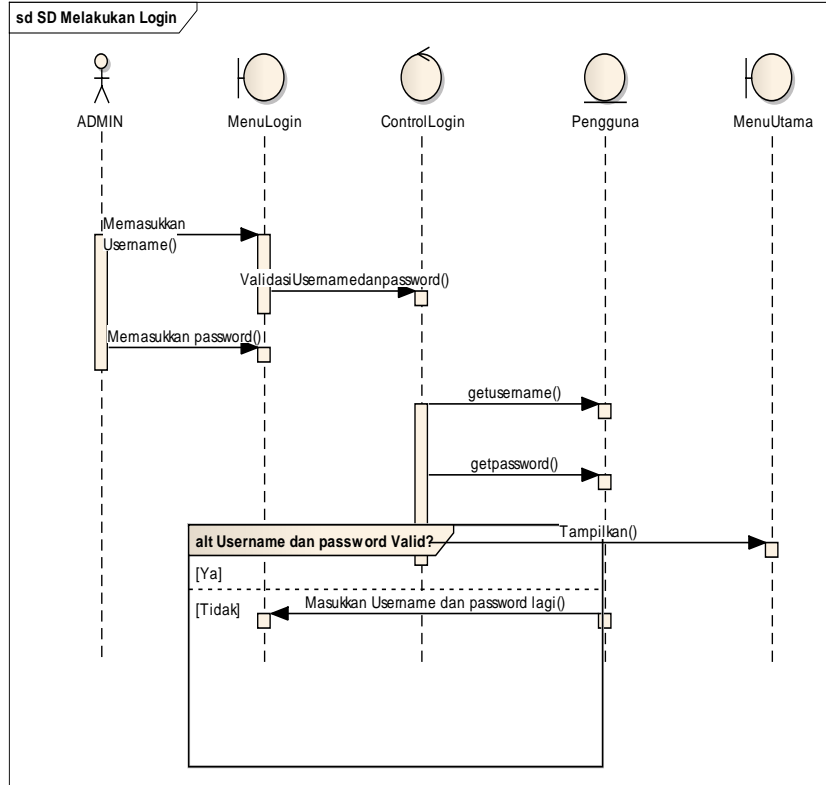

Gambar 10. Diagram Activity login admin

Diagram Sequence Mengelola Data Nasabah

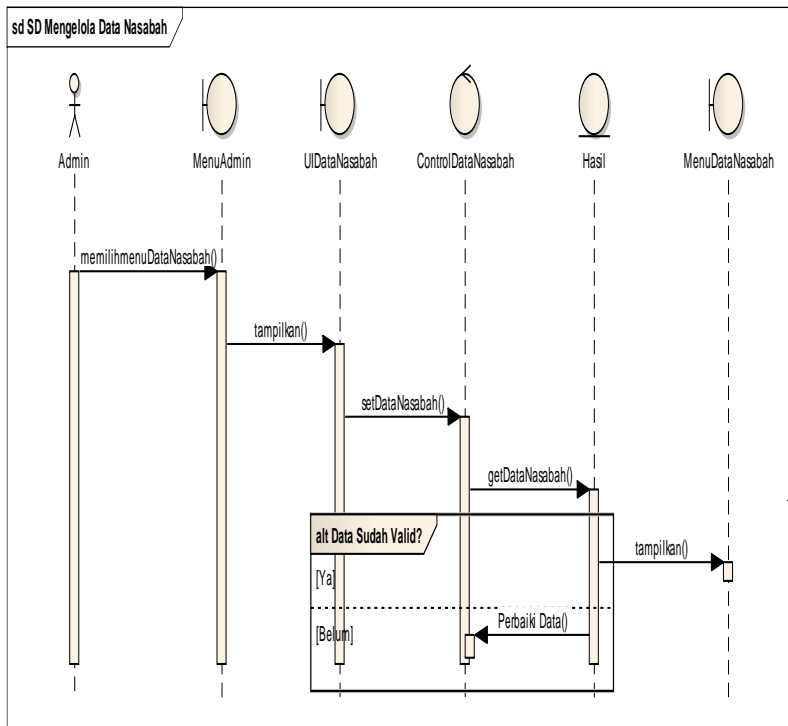

Gambar 11. Diagram Sequance Data

Nasabah

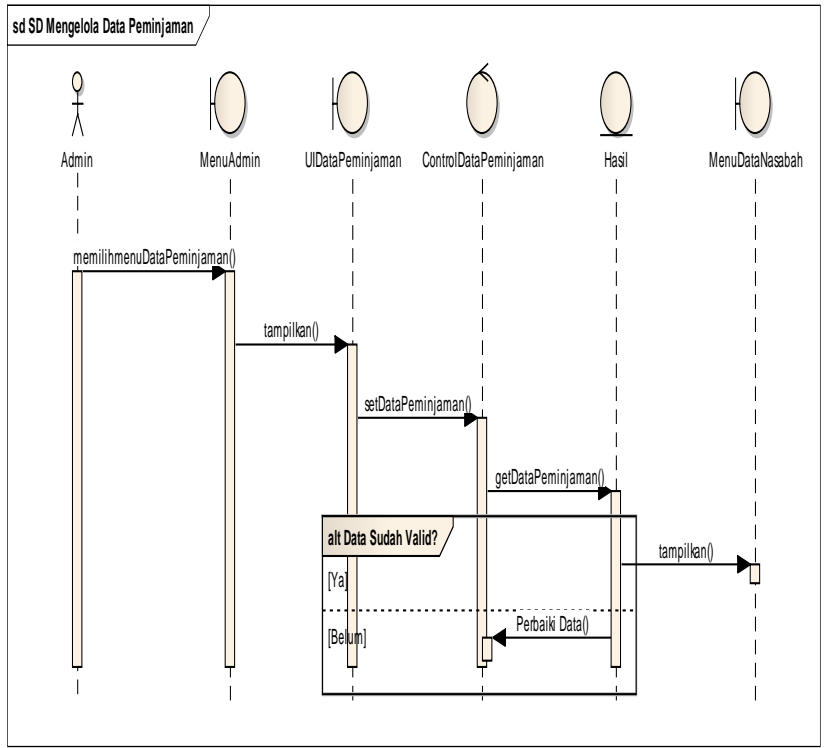

Gambar 12. Diagram Sequance Data Pinjaman

\section{Diagram Sequence Melihat Laporan}

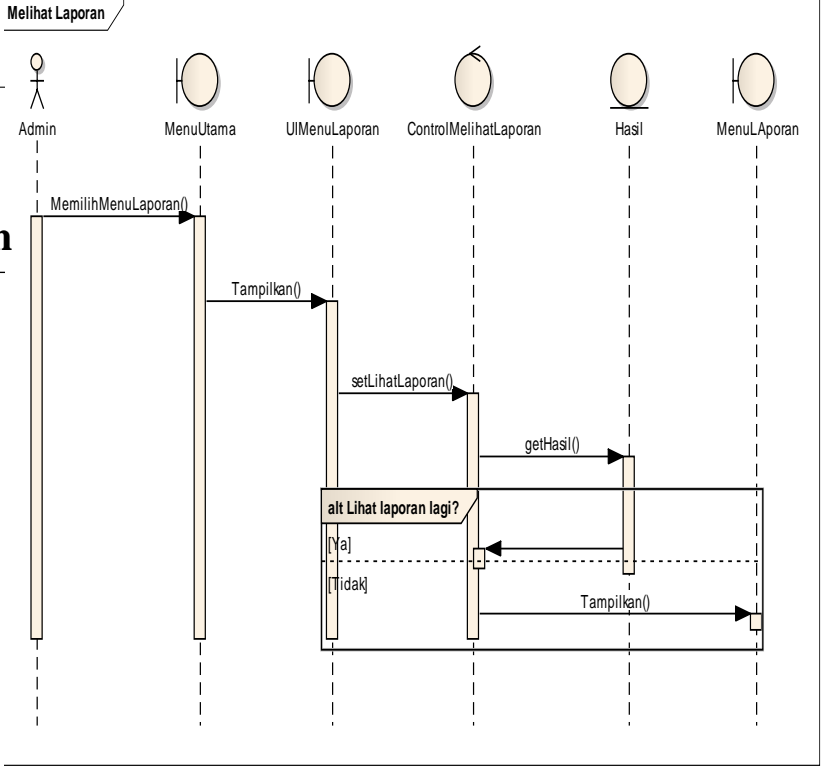

Gambar 13.. Diagram Sequance lihat laporan

Class Diagram

\section{Diagram Sequence Data Pinjaman}




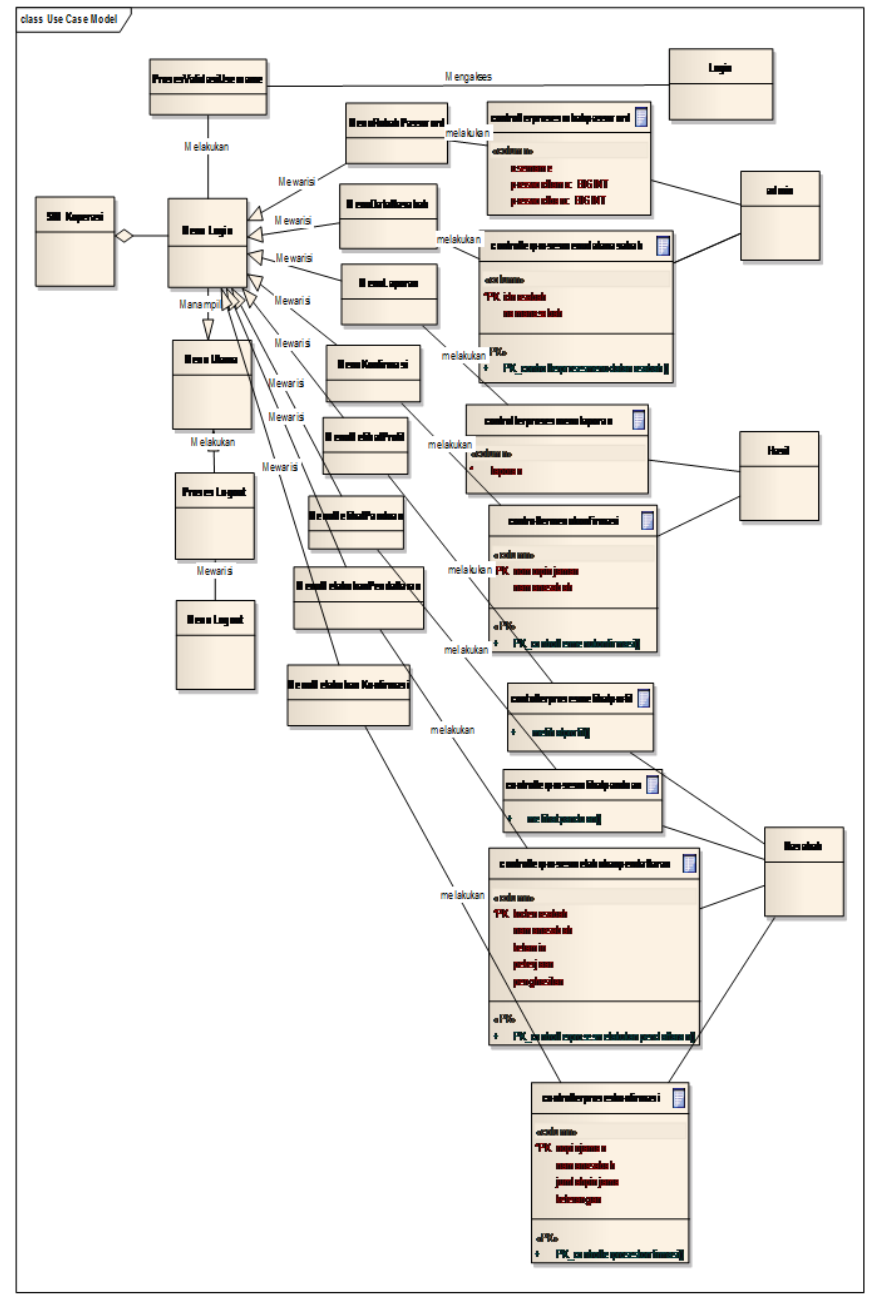

Gambar 14. Class Diagram

\section{Arsitektur Sistem}

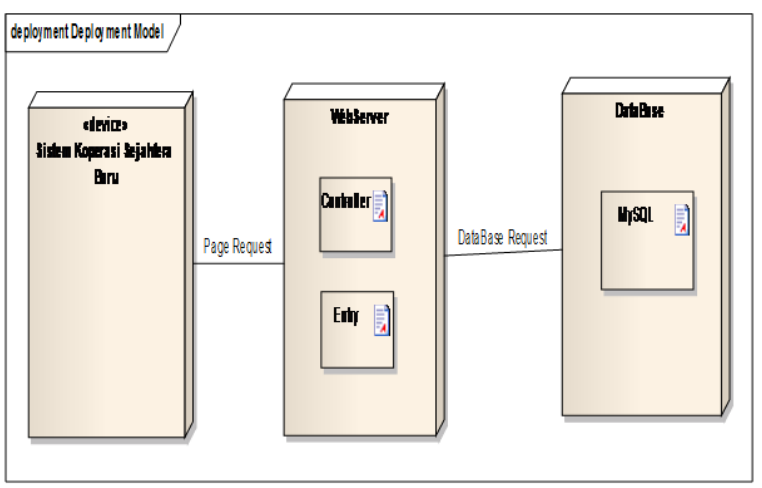

Gambar 15. Arsitektur sistem

\section{IMPLEMENTASI DAN PEMBAHASAN}

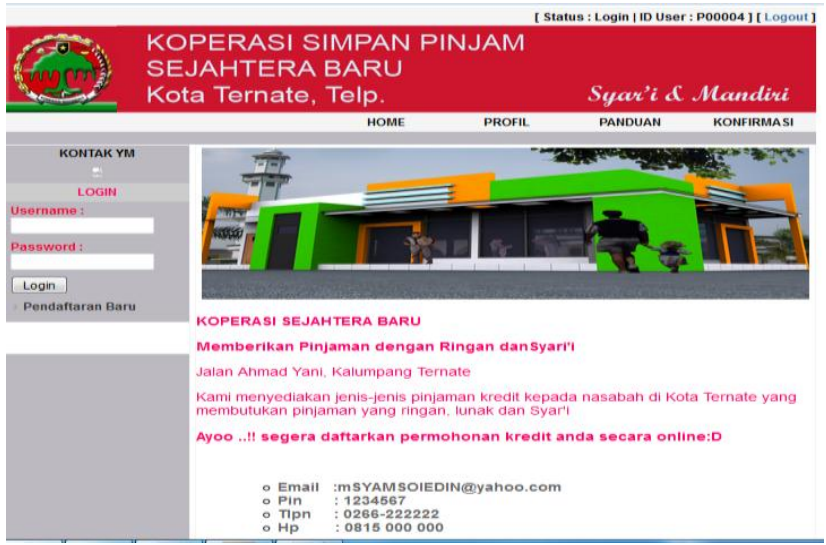

Gambar 16. Halaman Pengunjung

\section{Halaman Utama Admin}

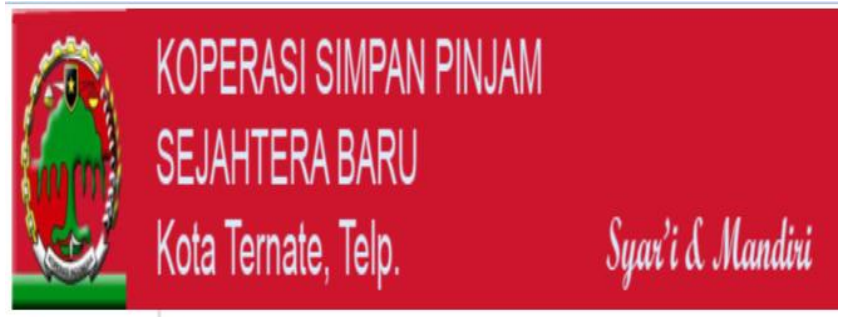

$$
\begin{aligned}
& \text { - hoes Selamat datang .....! }
\end{aligned}
$$

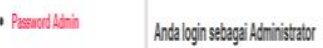

$$
\begin{aligned}
& \text { - Das lasiah } \\
& \text { - Kofimas Peneina Prignan } \\
& \text { - Lapran }
\end{aligned}
$$

Gambar 17. Halaman Admin

\section{Halaman Panduan}

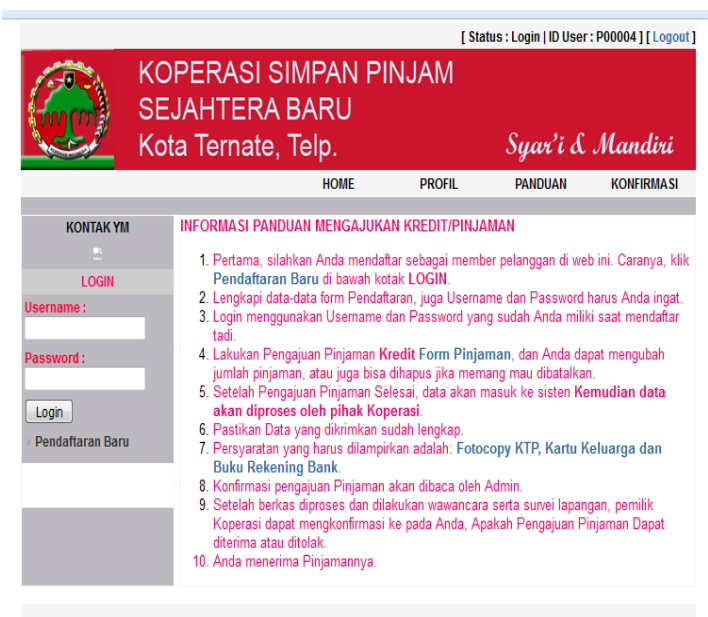

Gambar 18. Halaman Panduan

\section{Halaman Pinajaman}




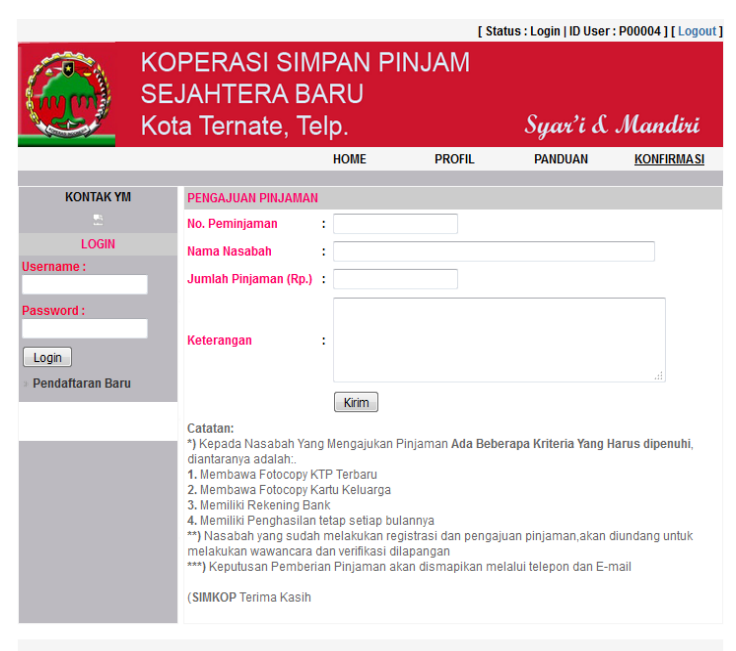

Gambar 19. Halaman Pinjaman

\section{Halaman Laporan}

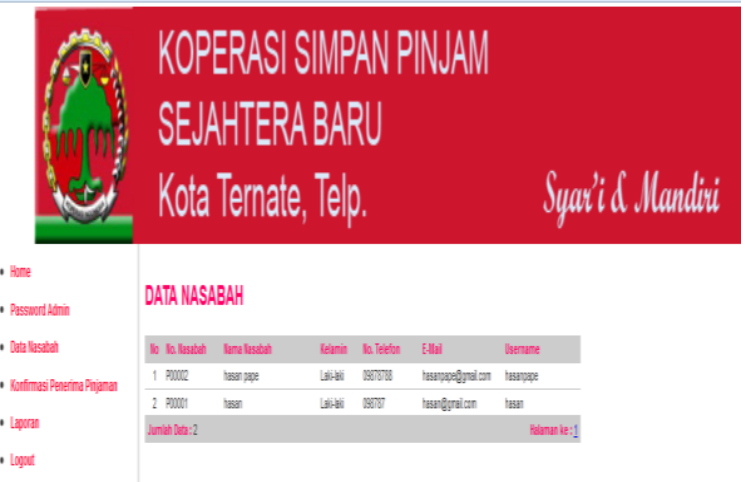

Gambar 20. Halaman Laporan

Tabel 6. Pengujian Login Pengguna

\begin{tabular}{|c|c|c|c|}
\hline \multicolumn{4}{|c|}{ HASIL UJI (Data Benar) } \\
\hline Input Dat & Tujuan & Pengamatan & Hasil \\
\hline $\begin{array}{l}\text { Username: } \\
\text { Admin } \\
\text { Password: } \\
\text { Admin }\end{array}$ & $\begin{array}{l}\text { Pengguna } \\
\text { masuk } \\
\text { ke halaman } \\
\text { Admin } \\
\text { dengan } \\
\text { benar }\end{array}$ & $\begin{array}{l}\text { Admin dapat } \\
\text { mengakases } \\
\text { halaman admin } \\
\text { sesuai dengan } \\
\text { yang } \\
\text { diharapkan }\end{array}$ & $\begin{array}{l}\mathrm{x}] \text { Terima } \\
\text { [ ] Tolak }\end{array}$ \\
\hline $\begin{array}{l}\text { Tombol } \\
\text { MASUK }\end{array}$ & $\begin{array}{l}\text { Mengarahkan } \\
\text { ke halaman } \\
\text { selanjutnya } \\
\text { untuk admin }\end{array}$ & 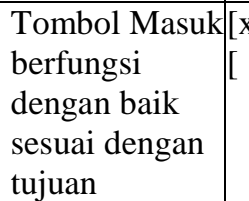 & $\begin{array}{l}\text { x] Terima } \\
\text { ] Tolak }\end{array}$ \\
\hline \multicolumn{4}{|c|}{ HASIL UJI (Data Salah) } \\
\hline $\begin{array}{l}\text { Input } \\
\text { Data }\end{array}$ & Tujuan & Pengamatan & Hasil \\
\hline $\begin{array}{l}\text { Username: } \\
\text { Admin } \\
\text { Pawossrd: } \\
12345\end{array}$ & $\begin{array}{l}\text { Tidak bisa masuk, } \\
\text { ada pesan } \\
\text { "Username dan } \\
\text { password anda }\end{array}$ & $\begin{array}{l}\text { Admin tidak } \\
\text { bisa masuk ke } \\
\text { halaman admin } \\
\text { dan ada pesar }\end{array}$ & \begin{tabular}{l|l}
$\mathrm{x}]$ \\
Terima \\
{$\left[\begin{array}{l}\text { n ] } \\
\text { Tolak }\end{array}\right.$}
\end{tabular} \\
\hline
\end{tabular}

salah, Silahkan

coba lagi"

Tabel 7. Pengujian Pendaftaran Nasabah baru

\begin{tabular}{|c|c|c|c|}
\hline \multicolumn{4}{|c|}{ HASIL UJI (Data Benar) } \\
\hline Input Data & Tujuan & Pengamatan & Hasil \\
\hline $\begin{array}{l}\text { Pengguna } \\
\text { Memasukkan } \\
\text { data nasabah } \\
\text { (Kolom } \\
\text { harus diis } \\
\text { semuanya, } \\
\text { tidak boleh } \\
\text { kosong) }\end{array}$ & $\begin{array}{l}\text { Data } \\
\text { nasabah } \\
\text { diproses } \\
\text { dan } \\
\text { disimpan } \\
\text { kedalam } \\
\text { database }\end{array}$ & $\begin{array}{l}\text { Dapat } \\
\text { melakukan } \\
\text { pengisian data } \\
\text { nasabah sesuai } \\
\text { dengan } \\
\text { keinginan }\end{array}$ & \begin{tabular}{|l}
{$[\mathrm{x}]$} \\
Terima \\
{$[\mathrm{]}$} \\
Tolak
\end{tabular} \\
\hline $\begin{array}{l}\text { Pilih Tombol } \\
\text { TAMBAH } \\
\text { dan } \\
\text { SIMPAN }\end{array}$ & $\begin{array}{l}\text { Dapat } \\
\text { melanjutkan } \\
\text { ke proses } \\
\text { selanjutnya }\end{array}$ & $\begin{array}{l}\text { Tombol yang } \\
\text { dipilh berfungsi } \\
\text { sesuai dengan } \\
\text { yang diharapkan }\end{array}$ & \begin{tabular}{|l|}
{$[\mathrm{x}]$} \\
Terima \\
{$[\mathrm{]}$} \\
Tolak
\end{tabular} \\
\hline \multicolumn{4}{|c|}{ HASIL UJI (Data Salah) } \\
\hline Input Data & Tujuan & Pengamatan & Hasil \\
\hline \begin{tabular}{|lr|}
\multicolumn{2}{|l|}{ Pengguna } \\
Memasukkan \\
data & nasabah \\
(ada & kolom \\
yang & belum \\
diisi) & \\
\end{tabular} & $\begin{array}{l}\text { Tidak dapat } \\
\text { melakukan } \\
\text { perintah } \\
\text { selanjutnya } \\
\text { ada pesan } \\
\text { "Kolom } \\
\text { tidak boleh } \\
\text { kosong" }\end{array}$ & \begin{tabular}{l|l} 
Data nasabah & [x \\
Tidak bisa & $\mathrm{T}$ \\
disimpan & [ \\
(harus \\
melakukan \\
input ulang)
\end{tabular} & $\begin{array}{l}\text { x] } \\
\text { erima } \\
\text { ] Tolak }\end{array}$ \\
\hline
\end{tabular}

Tabel 8. Pengujian Rubah Pasword Admin

\begin{tabular}{|c|c|c|c|}
\hline \multicolumn{4}{|c|}{ HASIL UJI (Data Benar) } \\
\hline Input Data & Tujuan & Pengamatan & Hasil \\
\hline $\begin{array}{l}\text { Pengguna } \\
\text { Memasukkan } \\
\text { password } \\
\text { lama dan } \\
\text { password } \\
\text { baru (Kolom } \\
\text { harus diisi } \\
\text { semuanya) }\end{array}$ & $\begin{array}{l}\text { Data } \\
\text { password } \\
\text { baru } \\
\text { diproses } \\
\text { dan } \\
\text { disimpan } \\
\text { kedalam } \\
\text { database }\end{array}$ & $\begin{array}{l}\text { Dapat } \\
\text { melakukan } \\
\text { perubahan } \\
\text { password } \\
\text { admin }\end{array}$ & $\begin{array}{l}{[\mathrm{x}]} \\
\text { Terima } \\
{[\text { ] }} \\
\text { Tolak }\end{array}$ \\
\hline $\begin{array}{l}\text { Pilih Tombol } \\
\text { SIMPAN, }\end{array}$ & $\begin{array}{l}\text { Dapat } \\
\text { melanjutkan } \\
\text { ke proses } \\
\text { selanjutnya }\end{array}$ & $\begin{array}{l}\text { Tombol yang } \\
\text { dipilih } \\
\text { berfungsi } \\
\text { sesuai dengan } \\
\text { yang } \\
\text { diharapkan }\end{array}$ & $\begin{array}{l}{[\mathrm{x}]} \\
\text { Terima } \\
{[\text { ] }} \\
\text { Tolak }\end{array}$ \\
\hline \multicolumn{4}{|c|}{ HASIL UJI (Data Salah) } \\
\hline Input Data & Tujuan & Pengamatan & Hasil \\
\hline $\begin{array}{l}\text { Pengguna } \\
\text { Memasukkan } \\
\text { data Password } \\
\text { (ada kolom } \\
\text { data } \\
\text { kunjungan } \\
\text { yang belum } \\
\text { diisi) }\end{array}$ & $\begin{array}{l}\text { Tidak dapat } \\
\text { melakukan } \\
\text { perintah } \\
\text { selanjutnya } \\
\text { ada pesan } \\
\text { "Kolom } \\
\text { tidak boleh } \\
\text { kosong" }\end{array}$ & $\begin{array}{l}\text { Data } \\
\text { Password } \\
\text { Tidak bisa } \\
\text { disimpan } \\
\text { (harus } \\
\text { melakukan } \\
\text { input ulang) }\end{array}$ & $\begin{array}{l}{[\mathrm{x}]} \\
\text { Terima } \\
{[\mathrm{]}} \\
\text { Tolak }\end{array}$ \\
\hline
\end{tabular}




\section{KESIMPULAN}

1. Penerapan Sistem informasi Perkreditan Koperasi Berbasis web sangat membantu masyarakat dalam mengajukan pinjaman, dimana masyarakat cukup mendaftar dngan cara mengakses website Koperasi Sejahtera Baru.

2. Proses pengolahan data menjadi lebih mudah, karena data terkoneksi ke dalam database sehingga memudahkan dalam proses pencarian, penambahan data dan perbaikan data. Selain itu System keamanan menjadi lebih baik, karena aplikasi dibuatkan system Login, dimana pengguna yang akan melakukan akses dibedakan menjadi dua, yaitu admin dan tamu, admin bisa melihat dan menginput semua data yang ada didalam aplikasi sedangkan Tamu/pengunjung hanya bias mengakses halaman depannya saja (front end).

\section{Saran}

1. Pada pengembangan selanjutnya aplikasi bisa dirancang lebih interaktif, dimana, system biasa memutuskan pinjaman nasabah dapat diterima atau ditolak

2. Membuat jadwal pemeliharaan terhadap system secara berkala baik itu menyangkut data atau informasi, hardware dan software.

\section{DAFTAR PUSTAKA}

Kasmir (2012). Bank Lembaga Keuangan Lainnya. Jakarta: Rajawali.

Muharto \& A. Ambarita (2016). Metode Penelitian Sistem Informasi: Mengatasi Kesulitan Mahasiswa Dalam Menyusun Proposal Penelitian.Yogyakarta. Deepublish
Peraturan Pemerintah Republik Indonesia Nomor 9 Tahun 1995 tentang Kegiatan Usaha Simpan Pinjam.

Sidik, Betha (2014). Pempograman Web, $P H P, M y S Q L, X A M M P$. Bandung: Informatika.

Sudarwanto, Adenk (2013). Akuntansi Koperasi; Pendekatan Praktis Penyusunan Laporan Keuangan. Yogyakarta: Graha Ilmu.

Taufiq, Rohma (2013). Sistem Informasi Manajemen. Yogyakarta: Graha Ilmu Supono, dan Putratama Vidiandry, 2016, Pemrograman Web dengan menggunakan PHP dan Framework Codeigniter, Yogyakarta: Deepublish.

Solichin, Ahmad. 2016. Pemrograman Web dengan PHP dan MySQL. Jakarta: BudiLuhur.

Fauzi dan Amin, Miftakul H. 2012. Pemograman Database Visual Basic 6 Dan SQL Server 2000. Yogyakarta: CV. ANDI OFFSET.

A.S Rosa, M.Shalahuddin. 2014. Rekayasa Perangkat Lunak Struktur dan Berorientasi Objek. Bandung: Informatika.

Duwi Cahya Putri Buani, Perancangan Sistem Informasi Koperasi Simpan Pinjam Studi Kasus: Koperasi SMK 18 LPPM RI Sidareja Cilacap, Junal Ilmu Pengetahuan dan Teknologi Komputer, Vol 3 No 1 Agustus 2017, eISSN:2527-4864

Dian Gigih Indrawati, Sistem Informasi Simpan Pinjam Pada Koperasi Sedai Kec. Tangen menggunakan PHP MySQL dan SMS Gateway, Naskah Publikasi Skripsi Tahun 2016, Jurusan Informatika Fakultas Komunikasi dan Informatika, Universitas Muhammadiyah Surakarta 